\title{
INFLUENCE OF TRADITIONAL COOKING METHODS ON PROXIMATE COMPOSITION, DIETARY FIBRE, KEEPING QUALITY AND CONSUMER PREFERENCE OF BIOFORTIFIED FERMENTED CASSAVA FUFU
}

\author{
*Amadi, Joy A.C. and Njoku, Sylvarlene, M. \\ Department of Nutrition and Dietetics, Imo State University P.M.B. 2000, Owerri, Nigeria. \\ *Corresponding author email: joyamadi@imsu.edu.ng +2347030987007
}

\begin{abstract}
Proximate, dietary fibre, keeping quality compositions and consumer preference of traditional prepared fufu were evaluated. Freshly harvested TMS419 and TMS1368 white root and yellow root cassava tubers weighing $30 \mathrm{~kg}$ respectively were purchased from Imo state Agricultural Development Programme (ADP). The cassava was peeled, washed, fermented for three days and sieved to get the cassava paste which was traditionally processed by boiling and stirring methods. The samples were labeled A (white boiled cassava fufu), B (white stirred cassava fufu), $C$ (yellow boiled cassava fufu) and D (yellow stirred cassava fufu). A cross-sectional study design was used in selecting 300 respondents using multi-staged sampling technique for consumer preference. A pretested, structured and validated questionnaire was used in collecting data from the respondents. Chemical analysis was carried out to determine the proximate composition, dietary fibre, microbial analysis, and consumer preference. Data was coded and analyzed using Statistical product for service solution (SPSS) version 22.0. Proximate composition showed that sample $D$ was significantly $(p<0.05)$ higher in moisture $(62.68 \%)$, protein $(1.43 \%)$, fat $(0.34 \%)$, fibre $(1.02 \%)$, ash $(0.60 \%)$, (37.00\%) and dietary fibre $(2.8 \%)$ while moisture was significantly $(p<0.05)$ higher in sample $D(62.68 \%)$. The result on microbial load showed that at day 3, sample A had the highest amount of microbial load $\left(9.67 \times 10^{5} \mathrm{cfu} / \mathrm{g}\right)$. Majority (76.0\%) of the consumers preferred boiling method of fufu preparation, 27\% preferred boiling method due to its aroma. More than half (55.3\%) and (51\%) reported that stirred fufu is easier to prepare and with high quality than boiled fufu respectively. This study observed that white cassava fufu was richer in nutrients, yellow cassava fufu had longer keeping quality and white boiled cassava fufu was mostly preferred.
\end{abstract}

Key words: Cassava fufu, boiling, stirring, dietary fibre, consumer preference https://dx.doi.org/10.4314/jafs.v17i1.2

\section{INTRODUCTION}

Cassava (Manihot esculenta) is a very popular high energy root crop consumed in the tropical and many regions of the developing world. It is a shrubby, tropical, perennial plant that is not well known in the temperate regions. It is the seventh most important crop of the world and constitutes a staple food for about $12.50 \%$ of the world population (Hans and Schlegel, 2005). Journal of the Faculty of Agriculture and Veterinary Medicine, Imo State University Owerri website: www ajol.info 
Cassava serves as a food security and income generation crop for millions of people in the developing world (Scott and Rosegrant, 2002). Despite their higher cyanides content, the bitter cassava varieties are more predominantly utilized (RMRDC, 2004). In order to alleviate vitamin A deficiency, cassava has been biofortified to get another variety of cassava popularly known as yellow root cassavas (Bouis and HandFresco, 2011). Cassava roots are processed in order to increase the shelf-life of their products, facilitate transportation, detoxify the products, and make the roots more palatable by providing a variety of products that are convenient to prepare and consume (Hipsey, 2003; Eglyst, 2001). There are different processing methods employed in cassava growing areas, which may include a combination of many of several procedures performed in specific sequences (Nweke, 2002). They includes, peeling, washing, crushing, slicing, chipping, pulping, soaking, drying, toasting, fermentation, and cooking.

Over the years, fufu has been a food mostly consumed by Nigerians and more especially a staple food in the South-Eastern part of the country. Fufu, a fermented cassava mash as a wet mash or a dry powder (Okpokiri et al., 2005) and is most commonly consumed in the eastern and southsouth zone of Nigeria. Traditional processes commonly used and their improved versions still involved peeling, cutting, soaking for 3 - 4 days, macerating, sieving to obtain the fufu and followed by drying when needed in dry powder (Okpokiri et al., 2005). However, the wet mash may yield fufu that has repulsive odour, poor keeping quality, and difficulty in handling of the wet mash. Fermentation has been viewed as a dynamic process during which several catabolic and anabolic reactions proceed simultaneously depending on several factors including substrate, micro flora and environmental factors (Eleazu et al., 2009). During the fermentation of cassava, the tissues are softened and disintegration of tissues by microorganisms' results in contact with cynogenic glucosides, linamarin and lotaustralin with the enzyme linamarase located in the cell wall (Mkpong et al., 2000) leading to the formation of glucose and acetone cyanohydrins which is spontaneously broken down to hydrocyanic acid (HCN) and acetone (Aworh, 2008).

There is an increasing drive to include food rich in fiber in the daily diet, and on those grounds, cassava could be a good source of dietary fiber (Tovar et al., 1989). An adequate intake of dietary fiber in the daily diet was promoted a long time ago as a consequence of observed beneficial effects in humans. Recent investigations have demonstrated that a high fiber diet could prevent or alleviate maladies such as cardiovascular diseases, diabetes, diverticulitis and colon cancer (Queen et al., 2007; Ogden and Bhatta, 2007). Dietary fiber which are found in fruits, vegetables, whole grain and tubers are indigestible portion of food derived from plants. Fufu contain significant amount of dietary fiber about $1.8 \mathrm{~g} / 100 \mathrm{~g}$, this also credits its health benefit (Ayetigbo et al., 2018). People have been consuming it without knowing the energy and nutrient content of the food. Most times, obese and diabetic patients are being advised to stop consuming fufu by their ignorant relatives probably because of its energy and caloric content.

Despite the importance of cassava as a major source of calorie and raw materials for industries, it still does not have an adequate and safe storage system presently. Oluwole and Ayetigbo (2000) observed that irregular and inadequate supplies of raw materials are major obstacles to industrial 
processing and utilization of cassava. Storage techniques for fresh fufu which include wrapping with polyethylene bags and storage in a cooler have been reported (Booth and Coursey, 2004). Preparations of cassava fufu vary from place to place and may have serious limitations at the commercial level. Therefore, this work was aimed at evaluating the effect of traditional cooking methods on proximate, dietary fibre, keeping quality and consumer preference of fermented cassava fufu.

\section{MATERIALS AND METHODS}

\section{Sample procurement}

Freshly harvested TMS419 and TMS1368 white root and yellow root cassava tubers weighing $30 \mathrm{~kg}$ respectively was purchased from Imo State Agricultural Development Programme (ADP). It was taken to crop science Department, Faculty of Agriculture and Veterinary Medicine, Imo State University for identification.

\section{Processing of the cassava}

The submerged fermentation process as described by (Booth and Coursey, 2004) was adopted. The cassava tubers were washed, peeled and fermented in water 3:1 (water/volume) for four days. After the stipulated time, the tubers were removed from the water and were sieved using $2.0 \mathrm{~mm}$ sieve and the fibrous materials were removed. The wet mash was allowed to sediment, packed in cloth bag and then pressed to remove water until a firm cake is obtained. The wet mash was divided into two equal parts of about $6.5 \mathrm{~kg}$ each for white and yellow cassava respectively.

\section{Processing of boiled fufu}

Six and half grams $(6.5 \mathrm{~g})$ of the cassava mash was moulded and introduced into boiling water and was allowed to boil for $20-25$ minutes at $100^{\circ} \mathrm{C}$, after which it was pounded and moulded again and introduced into boiling water and was allowed to boil for another 20 - 25 minutes then it was pounded again to get boiled fufu.

\section{Processing of stirred fufu}

Six and half grams $(6.5 \mathrm{~g})$ of the cassava mash were mixed with $50 \mathrm{ml}$ of water to form a uniform mash. The mash was stirred continuously over a low heat of $80^{\circ} \mathrm{C}$ for $20-30$ minutes to get the stirred fufu.

\section{Chemical analysis}

\section{Proximate analysis}

The samples were analyzed for proximate composition (\%protein, \%ash, \%fibre, and \% fat and $\%$ moisture) using methods by AOAC (2005). Carbohydrate was determined by difference. 


\section{Determination of dietary fibre}

Total dietary fiber (TDF) and insoluble dietary fiber content (IDF) was determined by an enzyme-gravimetric method described by Poulton (2008). Briefly, 0,5 $\mathrm{g}$ of sample was digested with thermostable $\alpha$-amylase (Sigma) at $\mathrm{pH} 6.0$ for $30 \mathrm{~min}$ at $100{ }^{\circ} \mathrm{C}$ and allowing to cool, then $\mathrm{pH}$ was adjusted to 7.5 and incubated with protease VIII (Sigma) for $30 \mathrm{~min}$ at $60{ }^{\circ} \mathrm{C}$. After cooling the sample was adjusted to $\mathrm{pH} 4.5$ and incubated with amyl glucosidase at $60{ }^{\circ} \mathrm{C}$ for 30 min. The sample was precipitated and reweighed crucibles containing celite (Sigma Chemical Co.) was use to filter the phase digested by the above enzymes. The residue was washed with ethanol and acetone.

\section{Fungi analysis}

One gram each of the fufu was separately homogenized in $9 \mathrm{ml}$ of distilled water. Tenfold serial dilution of each sample was performed until $10^{-4}$ level of dilution was obtained. $1 \mathrm{ml}$ of the lowest dilution $\left(10^{-1}\right)$ and other dilutions was pour plated on plates of nutrient agar and Sabouraud dextrose agar for the determination of microbial counts in each sample of the respective agar media, followed by incubation at laboratory (ambient) temperatures for 48 and 72 hours for fungal growth. Total viable counts of fungal were determined by enumerating the colony forming units ( $\mathrm{cfu} / \mathrm{g}$ ) at the end of the incubation period using the following formula as described by (Jideani and Jideani, 2006):

$\mathrm{c}=\mathrm{n} / \mathrm{vd}$

where;

c: Colony forming unit per gram (cfu/g)

n: Number of colonies

d: Dilution blank factor

v: Volume transferred to plate

The microorganisms isolated were sub-cultured by repeated streaking into sterile Sabouraud dextrose agar slants for fungal analysis until pure cultures was obtained.

\section{Characterization and identification of isolate}

The isolation and identification were done using the method of Ahlawat (2007) and International Commission on Microbiological Specification for Food (I.C.M.S.F.). Bacterial isolates were characterized and identified by initially examining colonies' morphology on their cultural properties followed by biochemical tests (Motility, citrate, coagulase, gram stain, catalase and oxidase). The fungal isolates on the other hand, were characterized by their cultural properties stained with cotton-blue lacto phenol solution and morphological observations under low power objective lens. 


\section{Consumer preferences evaluation}

\section{Survey area}

The study was conducted in Imo State. Imo State is one of the 36 States of Nigeria and lies in the South East of Nigeria. Owerri is its capital territory and the largest city.

\section{Survey design}

A cross sectional survey design was adopted for this study.

\section{Sampling population}

The sampling population was local producers and consumers in Imo State, Nigeria.

\section{Sampling techniques and selection}

A multi-staged sampling method was adopted for the study. In the three geopolitical zones in Imo State, a list of rural Local Government Area that engage in fufu making was used in selecting one rural Local Government Area using simple random sampling. From the selected Local Government Area, one autonomous community was selected. Their main market was used to evaluate fufu sellers preferred method of producing fufu. While for the consumers, a simple random sampling was used in selecting one village in the autonomous community. Each family was assigned a number and simple random sampling was used to select the number of families needed for the study.

\section{Sample size determination}

The sample size was calculated using the formula;

$$
\mathrm{n}=\frac{\mathrm{N}}{1+\mathrm{N}(\mathrm{e} 2)}
$$

Where;

$\mathrm{n}=$ sample size

$\mathrm{N}=$ population size

$1=$ constant

$\mathrm{e}=$ margin of error or test of significance

Therefore;

$$
\begin{aligned}
& \mathrm{n}=\frac{1200}{1+1200(0.05)^{2}} \\
& \mathrm{n}=\frac{1200}{1+1200(0.0025)} \\
& \mathrm{n}=\frac{1200}{1+3}
\end{aligned}
$$


$\mathrm{n}=\frac{1200}{4} n=300$

\section{Data collection}

A pre-tested, structured and validated questionnaire was used in collecting data from the respondents. The questionnaire was validated by three lecturers in the Department of Nutrition and Dietetics, Faculty of Health Sciences, Imo State University, Nigeria. The questionnaire was designed to elicit information on their personal characteristics like; sex, age, local government area and consumer preference on boiled and stirred fufu. Their reasons why they prefer each one, shelf life of the fufu, time of preparation etc. The questionnaire was given to them to fill but where the respondent is literate, the questionnaire was filled by the research assistants through oral interview and answers were recorded.

\section{Statistical analysis}

The data was analyzed using Statistical Product for Service Solution (SPSS) version 22.0. The mean and standard deviation were computed. Analysis of variance (ANOVA) was performed to determine significant differences between the means, while the means was separated using Ducan Multiple Range test. Significant difference was placed at $\mathrm{p}<0.05$.

\section{RESULTS}

\section{Proximate and dietary fibre composition of boiled and stirred cassava fufu}

Proximate composition shows that sample D was significantly $(\mathrm{p}<0.05)$ higher in moisture $(62.68 \%)$. However, sample A had highest values in protein $(1.43 \%)$, fat $(0.34 \%)$, crude fibre $(1.02 \%)$, ash $(0.60 \%)$, carbohydrate $(37.00 \%)$ and dietary fibre $(2.8 \%)$. Significant $(p<0.05)$ differences existed among all the samples.

\section{The microbial load of fufu}

The microbial load present in boiled and stirred yellow and white cassava fufu after a day, three days and seven days are represented in table 2 below. There was significant difference $(\mathrm{p}<0.05)$ in the microbial load present after day 1, 3 and 7 days. After a day, sample B had the highest amount of microbial load $\left(9.38 \times 10^{3} \mathrm{cfu} / \mathrm{g}\right)$ while sample A had the lowest microbial load $\left(2.06 \times 10^{3} \mathrm{cfu} / \mathrm{g}\right)$ present. At day 3, Sample B still had the highest microbial load but it however increased slightly $\left(9.48 \times 10^{3} c f u / g\right)$ while sample A still had the least microbial load although with a double increase $\left(4.13 \times 10^{3} c f u / g\right)$. At day 7 , the microbes present was discovered to be lowest in sample B $\left(1.12 \times 10^{5} \mathrm{cfu} / \mathrm{g}\right)$ and highest in sample A $\left(9.67 \times 10^{5} \mathrm{cfu} / \mathrm{g}\right)$.

\section{Physical attributes of fufu stored for seven days}

The physical attributes (colour and odour) changes in the boiled and stirred white and yellow cassava fufu are shown in tables 3 a to $3 \mathrm{~d}$ below. On day 1 to 3 , no visible change was observed in the boiled and stirred white fufu. On day 4, white spots and change in odour was observed. By 
day 6, there was further spoilage and marked changes in the colour and odour. There was no visible change observed in the yellow stirred and boiled cassava fufu from day 1 to 4 . The colour however changed and a mouldy smell was perceived from the fifth day. The colour and odour change became pronounced at day 6 and 7 .

\section{Consumers' Preference of Fufu}

\section{Socioeconomic characteristics of the respondents}

Table 4 shows the socioeconomic characteristics of the respondents. Majority (66.3\%) of the respondents were females while $33.7 \%$ of the respondents were males. Thirty five percent of the respondents were within the age range of 41-50 years, 33.0\% (31-40 years), 17.3\% (51-60 years) while $14.7 \%$ (20-30 years). Greater number $(49.3 \%)$ of the respondents was married, widowed $(26.3 \%)$, single $(20.0 \%)$ while divorced $(4.0 \%)$. About thirty five percent of the respondents had WASC, FSLC (26.0\%), first degree $(24.0 \%)$, no formal education $(12.3 \%)$, masters degree $(2.7 \%)$ while Ph.D $(0.3 \%)$. About forty three percent of the respondents are traders; civil servants $(40.0 \%)$ while public servants $(16.3 \%)$. Some $(41.3 \%)$ of the respondents had monthly income of $<$ <0,000, <\#10,000 (33.7\%), <\#100,000 (19.3\%) while > $100,000(5.7 \%)$.

\section{Consumer preference}

Table 5 shows the consumer's preferences on boiled and stirred fufu. Majority (76.0\%) of the respondents preferred boiling method for the preparation of fufu while $24.0 \%$ of the respondents preferred stirring method for the preparation of fufu. Most (75.7\%) of the respondents make use of boiling method in the preparation of fufu while $24.3 \%$ of the respondents make use of stirring method in the preparation of fufu. Twenty seven percent of the respondents gave reason for preferment of preparation method due to its aroma, 22.7\% (texture), 19.0\% (taste), 12.7\% (longer shelf life) and $6.7 \%$ (colour). Most $(55.3 \%$ ) and 51\% reported that stirred fufu is easier to prepare and with high quality than boiled fufu respectively. On the problems encountered in fufu preparation, about forty-five respondents reported that much energy is exerted during preparation, much water is not required $(32.2 \%)$ and peeling of cassava takes time $(18.0 \%)$. On what should be done to improve cassava preparation, $57.3 \%$ of the respondents reported use of automated machine, fairly prepared fufu should be made available (18.0\%) while $24.7 \%$ did not respond.

\section{DISCUSSION}

\section{Proximate and dietary fibre composition of Boiled and Stirred cassava fufu}

The moisture content of the samples was higher compared with the moisture content of $58.80 \%$ recorded by Omosuli et al. (2017) from fufu prepared from cassava flour in their study. It was however lower than the moisture content of $72.25 \%$ recorded by Adetunji et al. (2017) from fufu gotten from different market in Ilorin West. The different variation recorded in the moisture content of the fufu from the various studies might be due to the fact that some level of Journal of the Faculty of Agriculture and Veterinary Medicine, Imo State University Owerri website: www ajol.info 
transpiration occurs after the processing of cassava tubers into fufu (Ikujenlola et al., 2007). The variation in the moisture content observed from the various fufu samples in this study might be due to their ability to absorb moisture during storage condition which subsequently supports the colonization of these spoilage fungi as well as increase their deteriorative capabilities. The moisture absorbed by the fufu samples enhanced the biodegradability potential of these microorganisms (Jonathan et al., 2016). Traditionally, fufu is sold as a wet paste and this renders it highly perishable with a reduce shelf life (Tomlins et al., 2009).

Low protein content of the fufu confirm with the nutritional components of cassava root where carbohydrate is mainly the nutritional component of which $80 \%$ is starch (Purseglove, 2009). The protein content in this study was however lower than the result gotten by Etudaiye et al. (2012) which ranged from $2.10 \%$ to $2.46 \%$ in studying the nutritional quality of fufu from selected cassava mosaic disease resistant cultivars. The low protein of fufu is not a serious issue as fufu is usually consumed accompanied with different protein sources both of animal and vegetable origin from different soups (Etudaiye et al. (2012). Montagnac et al. (2009) reported a number of attempts to improve protein in cassava by biofortification and post-harvest processing, with some recorded successes. Ayetigbo et al. (2006) also reported that the protein content was significantly higher in white fleshed cassava variants than yellow fleshed variants. Hence, protein content in cassava fufu could be variant dependent which is consistent to this study where the result showed that the protein content was higher in white cassava fufu than in yellow cassava fufu.

Low fat content obtained was in line with previous study that cassava root is a poor source of lipids (Jalakudin, (2009). Fats are vital to the structure and biological functions of cells which are used as alternative energy source. Also, Ayetigbo et al. (2006) reported fat content of 0.2 to $3.66 \%$ for white flesh cassava and 0.29 to $3.2 \%$ for the yellow fleshed cassava in their study on comparing the characteristics of yellow and white flesh cassava variants. This was consistent with the results gotten in this study. It was observed in this study that the fat content of the stirred white and yellow cassava fufu was lower than that of the boiled. This observation could be as a result of the species of the cassava used. About half of lipids in cassava roots are non-polar or in glycolipid forms. The fibre content of the cassava fufu depends on the specie and also the age of the cassava at harvest (Montagnac and Davis, (2009). Relatively high fibre content between $0.62 \%$ to $4.92 \%$ has been found in roots of white flesh cassava specie than in yellow flesh specie (Ukenye et al., 2013). Likewise, crude fibre in cassava fufu is generally higher in white fufu than in the yellow fufu (Aniedu and Omodamiro, 2012). This was consistent with the present study where the results showed higher crude fibre content in the white boiled and stirred cassava than in the yellow boiled and stirred cassava. The difference in fibre content contributes to the high dry matter in the white fleshed variants than in the yellow fleshed ones. Crude fibre represents that portion of food not used up by the body but mainly made up of cellulose together with a little lignin and is known to increase bulk stool (Eleazu et al., 2011). Crude fibre consists largely of cellulose and lignin plus some mineral matter. 
The ash content is an important component of cassava and is an indication of the mineral richness and non-volatile content of cassava (Montagnac and Davis, 2009). In this study, the total non-existant incinerable matter (ash) of the fufu was reported to be higher in the white boiled cassava fufu than in the yellow stirred cassava. They study was similar to (Ogden and Bhatt, 2006) on the ash content of yellow and white cassava. The difference may be attributed to the traditional methods of processing used. Processing of cassava has been reported to significantly reduce ash content of the roots with a similar trend for minerals (Ogden and Bhatt, 2006). Hence, several processing techniques such as those involving application of high temperature and excessive fermentation, washing and milling treatments could significantly reduce ash content in cassava (Ogden and Bhatt, 2006). In this study, the carbohydrate content of white flesh cassava was significantly $(\mathrm{p}<0.05)$ higher than that of yellow fleshed. However, genotypic differences and age can also cause differences in carbohydrate content between different species. The result of this study was consistent with Ukenye et al. (2013) who also reported high carbohydrate content in the white cassava fufu than in the yellow fufu. Also, the carbohydrate content of the stirred cassava fufu was lower than the boiled cassava fufu. On the contrary, Okolie et al. (2012) reported lower higher carbohydrate content of $85.8 \%$. The reduction in carbohydrate content of fufu samples may be due to the preliminary loss of soluble carbohydrate during the processing of the cassava tubers.

Dietary fibre refers to nutrients in the diet that are not digested by gastrointestinal enzymes but still fulfil an important role (Trowell et al., 2005). It is mostly found in vegetables, fruits and whole grains and aids in reducing the risk of heart disease and diabetes. Root/tuber crops are good sources of dietary with up to $14 \%$ content (Patel et al., 2012). The dietary fibre content observed in this study was observed to be very low compared to that reported by Onodu et al. (2018) who reported dietary fibre of $4.6 \%$ in fufu. This may be attributed to the variety of cassava tuber. The result indicated that both the white and yellow boiled cassava fufu had higher dietary fibre content than that of the stirred cassava fufu. This may be attributed to the traditional stirring method used. However, Ming-Cheng, (2011) in their study on the effect of heat treatment on dietary fibre concluded that the effect of processing on the total dietary fibre appears to be dependent upon the fibre source and the processing methods used.

\section{The microbial load of fufu}

White boiled cassava fufu had the highest total microbial load at the seventh day. Spoilage in the white boiled and stirred cassava fufu was observed after the third day while the yellow boiled and stirred cassava fufu started spoilage after the fourth day. This indicates that white cassava fufu spoils faster than yellow cassava fufu. Although higher moisture content was observed in the yellow cassava fufu than the white cassava fufu in this study, the nutritional content of the samples favours the growth of microorganisms (Odum et al., 2012). The result revealed an increase in microbial count among the samples as the storage days increased (Odum et al., 2012). The microbial load observed in this study was lower when compared with Adebayo-Oyetoroet Journal of the Faculty of Agriculture and Veterinary Medicine, Imo State University Owerri website: $w w w$ ajol.info 
al. (2013) who reported microbial load of $8.4 \times 10^{6} \mathrm{Cfu} / \mathrm{g}$ from fermented cassava fufu. The isolated microorganisms present in fufu might be as a result of the processing methods and poor handling practices which can further increase microbial hazards (Adebayo-Oyetoro et al. 2013). The microorganisms isolated from the fufu samples could be organisms involved in the fermentation hence the fermentation employed for the fufu product was natural fermentation where complex microbial population are involved during fermentation. Though this might be the situation, it cannot be ignored that some of these organisms could be contaminants from humans, packing material, storage temperature, $\mathrm{pH}$ and even the immediate environment where the prepared cassava was stored (Odom et al., 2012).

\section{Sensory attribute of fufu stored for seven days}

In the sensory attribute of fufu, the colour and the odour change became pronounced on day 6 and day 7 and was consistent with Obandina et al. (2007) on some fermented cassava products (lafun, fufu, gari). The strong mouldy odour observed in the spoilt fufu could be attributed to volatile product of carbohydrate by saccharolytic microorganisms such as yeast. The observed colour change may be as a result of oxidation and interaction of metabolic products (Njoku et al., 2012).

\section{Socioeconomics characteristics of the respondents}

The study observed that more women are involved in fufu production and marketing. This was because as far as cassava production is concern as observed by TADENA (2004)), access and use of land for cassava production is not gender biased. Either of the sexes can get involved in cassava production. There was no bias when it comes to providing access to farmland for women in the study area especially when it involves production of staple crops like cassava, maize, yam etc. Almost half of the respondents used in this study were married. This could be because most the respondents are within their child bearing age. This was in agreement with the Nigerian average age for marriage (17 and above) reported by the national baseline survey of positive and harmful traditional practices affecting women and girls in Nigeria (UN, 2008). Majority of the respondents had one form of education or other with secondary education accounting for a higher proportion. The level of secondary school education reported in this study was lower than that reported among a group of traders (38\%) in Ikoshi-Isheri, Lagos State (Akinloye, 2010). About forty three percent of the respondents are traders. This suggests that, as part of the survey was conducted at the market place, it is likely that most of the respondents were traders in the market. About forty one percent of the subjects had monthly income $<\$ 50,000$. This shows that fufu sale could be a better business.

\section{Consumers' preferences on boiled and stirred fufu}

The study observed that most people preferred boiled fufu to stirred fufu. This result agrees with results of Laswai et al. (2005) and Silayo et al. (2004) who found that the high-quality boiled cassava products were mostly preferred by people. Though the study observed that majority of the respondents stated that stirred fufu is easier to prepare and has higher quality. This suggestion 
was based the on time they spend on the preparation of boiled fufu. Most of the respondents stated that the major problem faced during fufu preparation was that much energy is required especially during pounding of fufu and suggested that to improve fufu preparation, automated machine that reduces the time frame and energy needed should be developed. This shows that, the introduction of cassava processing technology could be easily adopted in the study area because most of the respondents have formal education and eager to make use of the machine to reduce stress faced during fufu preparation.

\section{CONCLUSION}

This study observed that white cassava fufu was richer in nutrients such as protein, fat, crude fibre, ash (minerals) and dietary fibre but comparable with yellow cassava fufu. The study also revealed that the yellow cassava fufu tend to store better than the white fufu. It was also observed that people preferred boiling method of preparing fufu to stirred method. Therefore, yellow fleshed cassava fufu are recommended for commercialized cultivation. Therefore, breeding efforts to bridge the gap in properties observed in both types of species could hold the key to nutritional and functional uses of yellow cassava fufu just as much as white cassava fufu. 


\section{REFERENCES}

Adebayo-Oyetoro, A. O., Oyewole, O. B and Obadina, A. O. (2013). Microbiological safety assessment of fermented cassava fufu available in Ogun and Oyo states of Nigeria. International Journal of Food Science; 1(5):255-260.

Adetunji, C. O., Akande, S. A and Oladipo, A. K. (2017). Determination of the microbiological quality and proximate composition of fermented cassava food products sold in Ilorin West local government area, Nigeria. Ruhuna Journal of Science; 8:76-89.

Ahlawat, B.B. (2007). Medical Laboratory Practical. New Delhi UDH publishers and distributors.

Akinloye, I. A. (2010). Fermentation of cassava Journal of the Science of Food and Agricultural; 9:589-594

Aniedu, C and Omodamiro, R. M. (2012). Use of Newly Bred B-carotene cassava in production of value-added products: Implication for Food Security in Nigeria. Global Journal of Science; 12:10-16.

AOAC, (2005). Official methods of analysis 18th edition. Arlington, V. An Association of Official Analytical Chemist: 806-842.

Aworh, O. C. (2008). The role of traditional food processing technologies in national development: The West African experience. Chapter 3 from Using Food Science and Technology to Improve Nutrition and Promote National Development.

Ayetigbo, O., Sajid, L and Muller, J. (2018). Comparing Characteristics of Root, Flour and Starch of Biofortified yellow -flesh and white -flesh cassava variants and Sustainability Considerations. A Review. International Institute of Tropical Agriculture.

Booth, R. H, and Coursey D. G. (2004). Cassava processing and storage. Proceedings of International workshop. Pattaya, Thailand, 17-19, April.International Development Research Centre Ottowa, Canada. :43- 49.

Bouis, G and Hand Fresco, L. O. (2011). The importance of cassava in world food production. Netherlands Journal of Agricultural Sciences; 37:21:34.

Eglyst, M. (2001). Cassava processing and Biotechnology: Proceedings of $1^{\text {st }}$ International Sicntific Meeting of the cassava biotechnologies network. Cartagenia de India, Columbia. 25-28 August. W. M. Roca and A. M. Thro. Eds.

Eleazu, C. O., Amajor, J. U and Ikpeama, A. I. (2011). Studies on the nutrient composition, Antioxidant activities, functional properties and microbial load of the flours of 10 elite cassava (Manihot esculenta) varieties. Asian Journal of Clinical Nutrition; 3:33-39.

Etudaiye, A. H, Nwabueze, T and Sanni, O. L. (2012). Nutritional Quality and Preference of fufu processed from selected Cassava Mosaic Disease (CMD) Resistant Cultivars. Pelagia Research Library; 3(5):2687-2692. 
Hans, G. and Schlegel, N. U. (2005). General microbiology, $7^{\text {th }}$ edition (cambrige low price editions). Published by the press syndicate of the University of Cambridge. Page. 290-332.

Hipsey, G. S. (2003). Effect of retting on cassava product yield and cyanide detoxification, Journal of Food Technology; 20 (1):89-96

Ikujenlola, A. V and Opawale B. O. (2007). Effects of Processing on the Yield and Physicochemical properties of Cassava Products. Advanced Material Research; 18:165-170.

Jalakudin, S. (2009). Cassava as feed stuff for livestock. In: Devendra, C: Hutagalung, R. I. Feed stuff for livestock in South East Asia; 158-159.

Jideani, I. A and Jideani, V. (2006). Developments on the cereal grains Digitariaexilis (acha) and Digitariaiburua (iburu). Journal of Food Science and technology Mysore-48(3):251-9

Jonathan, S. G., Adeniyi, M. A and Asemoloye, M. D. (2016). Nutrient value, fungal biodeterioration and aflatoxin contamination of suya species a novel. Nigerian indigenous snack. Hindawi Scientifica 2016:ID 4602036.

Laswai, H. S., Silayo, V. C. K., Mpagalile, J. J., Ballegu, W. R. and John, J. (2005). Improvement and popularization of diversified cassava products for income generation and food Security: A case study of Kibabu. African Journal of Food, Agriculture and Nutrition Development; 6(1): 1 - 15.

Ming-Cheng, G. (2011) High-carbohydrate, high- fibre diets for insulin- treated men with diabetes mellitus. American Journal of Clinical Nutrition; 32:2312-2321

Mkpong, O. E., Hau-Yan E., Chism G., and Sayre, R. T. (2000). Purification, characterization and localization of linamarase in cassava. Plant Physiology; 93: 173 - 181.

Montagnac, J. A and Davis, C. R. (2009). Nutritional value of Cassava for use as a Staple Food and Recent Advances for Improvement. Journal of Food Science; 8:181-194.

Njoku, O. B., Samuel, L. O, Adebayo, K and Ayinde, I. A. (2012). Improved processing technology for the fermentation of cassava to 'fufu'. 35th Annual Conference and AGM of Nigeria Institute of Food Science and Technology. Makurdi.

Nweke, M. (2002). Cassava processing and Biotechnology, Department of Agriculture, Federal Ministry of Agriculture and Natural Resources Lagos Nigeria htt/wwwglobal cassava strategy.net/Africa/Nigeria

Obadina, A.O., Oyewole, O.B and Odubayo, M.O. (2007). Effect of storage on the safety and quality of "fufu" flour. Journal. Food Safety; 27: 148-156.

Odom, T. C., Nwanekezi, E. C, Udensi, E. A., Ogbuji C. A., Ihemanma C. A., Emecheta R. O. and Aji R. U. (2012). Biochemical qualities of cassava fufu sold in Imo and Abia States of Nigeria. Global Advanced Research Journal of Environmental Science and Toxicology; 1(7):178-182. 
Ogden, E. O and Bhatt, R. B. (2006). Traditional preparation and uses of cassava in Nigeria. Economic Boltany; 39 (2): 157-167

Okolie, N. P., Brai, M and Natoyebi, O. M. (2012). Comparative Study on Some Selected Fufu samples sold in Lagos Metropolis. Journal of Food Studies; 1(1):1-10.

Okpokiri, R. M., Oti, E., Egesi, C. N., Ukpabi, U. J., Etudaiye, H. A and Chijioke, U. (2005). Sensory Evaluation of Fufu produced from high $\beta$-carotenoid cassava. In: 35th Annual Conference and AGM of Nigeria Institute of Food Science and Technology. Makurdi.

Omosuli, S. V., Ikujenlola, A. V and Abisuwa, A. T. (2017): Quality assessment of stored fresh cassava roots and 'fufu' flour produced from stored roots. Journal of Food Science and Nutrition Therapy 3(1):9-13.

Onodu, F., Alfred, A and Okon, J. L. (2018) Relationships between physical characteristics of sugar beet fibre and its fermentability by human fecal flora. CarbohydrPolym; 37:185-197

Oyewole, O. B and Odunfa, S. O. (2000). Characterization and distribution of Lactic acid bacteria in cassava fermentation during fufu production. Journal. of Applied Biotechnology; 68:145 -152 .

Patel, D. K., Prasad, S. K, and Kumar, R. (2012). An overview on antidiabetic medicinal plants having insulin mimetic property. Asian Pacific Journal of Tropical Bio medicine; 2:320-30.

Poulton, J. E. (2008). Localization and Catabolism of Cyanogenic Glycosides. In Cyanide Compunds in Biology; Rvered, D.and Harnett, S., Eds.; John Wiley \& Sons: Chichester, UK. : 67-71.

Purseglove, J. W. (2009). Dicotyledons: Longman Scientific and Technical, co-published in the United States with John Wiley and sons, New York.

Queen, H. A., Nwabueze, T. U., Sanni, L. O and Oti, E. (2007). Pasting properties of fufu processed from selected cassava mosaic disease (CMD) resistant varieties in Umudike, Abia state. Proceedings of the 32 annual conference and AGM held at Ladoke Akintola University, Ogbonosho, Nigeria: 314-315.

RMRDC (2004): Raw materials Research and development council; Federal ministry of Science and Technology Abuja. Report on survey of Agro Raw materials in Nigeria; Cassava (Maiden Edition), October, 2004. Amana printing and advertising :1 -117.

Scott, G. J and Rosegrant, M. W. (2002). Roots and tubers for the $21^{\text {st }}$ century.

Silayo, V. C. K., Mpagalile, J. J., Ballegu, W. R. W., Mtunda, K., Chilosa, D., Nyborg, I. and Makungu, P. J. (2004). Processing and utilization of cassava. Swahili monograph. TARPIISUA project: 33 .

TADENA (2004). Promoting the use of Appropriate Technologies and Entrepreneurial Skills in Cassava Production and Processing in Tanzania. Twende Associates Reports: 8. 
Tovar, J., Bjorck, I.M. and Asp, N.G. (1989). On the nutritional properties of starch and dietary fiber in cassava bread. Nutrition Reports International; 39(6):1237-46.

Trowell, H., Burkitt, D., Heaton, K. (2005) Definitions of dietary fibre and fibre-depleted foods and disease. Academic, London, 21-30

Ukenye, E, Ukpabi U. I and Chijoke, U. (2013). Physicochemical, Nutritional and Processing Properties of Promising Newly Bred White and Yellow Fleshed Cassava Genotypes in Nigeria. Pakistan Journal of Nutrition; 12:302-305.

UN (2008). National baseline survey of positive and harmful traditional practices affecting women and girls in Nigeria. 
Journal of Agriculture and Food Sciences

Amadi, Joy A.C. and Njoku, Sylvarlene M.

33 Volume 17 Number 1, April 2019 pp

18- 37

TABLE 1: Proximate composition and dietary fibre of stirred and boiled fufu

\begin{tabular}{llllllll}
\hline Sample & Moisture (\%) & Protein $(\%)$ & Fat $(\%)$ & $\begin{array}{l}\text { Crude fibre } \\
(\%)\end{array}$ & Ash $(\%)$ & $\begin{array}{l}\text { Carbohydrate } \\
(\%)\end{array}$ & Dietary fibre \\
\hline A & $60.14^{\mathrm{d}} \pm 0.01$ & $1.43^{\mathrm{a}} \pm 0.01$ & $0.34^{\mathrm{a}} \pm 0.01$ & $1.02^{\mathrm{a}} \pm 0.01$ & $0.60^{\mathrm{a}} \pm 0.01$ & $37.00^{\mathrm{a}} \pm 0.01$ & $2.80^{\mathrm{a}} \pm 0.01$ \\
B & $60.85^{\mathrm{c}} \pm 0.01$ & $1.38^{\mathrm{b}} \pm 0.01$ & $0.32^{\mathrm{b}} \pm 0.01$ & $1.00^{\mathrm{b}} \pm 0.01$ & $0.58^{\mathrm{b}} \pm 0.01$ & $36.50^{\mathrm{b}} \pm 0.01$ & $2.65^{\mathrm{c}} \pm 0.01$ \\
C & $62.13^{\mathrm{b}} \pm 0.01$ & $1.29^{\mathrm{c}} \pm 0.01$ & $0.28^{\mathrm{c}} \pm 0.01$ & $0.96^{\mathrm{c}} \pm 0.01$ & $0.55^{\mathrm{c}} \pm 0.01$ & $35.80^{\mathrm{c}} \pm 0.01$ & $2.72^{\mathrm{b}} \pm 0.01$ \\
D & $62.68^{\mathrm{a}} \pm 0.01$ & $1.22^{\mathrm{d}} \pm 0.01$ & $0.26^{\mathrm{d}} \pm 0.01$ & $0.92^{\mathrm{d}} \pm 0.01$ & $0.52^{\mathrm{d}} \pm 0.01$ & $34.40^{\mathrm{d}} \pm 0.01$ & $2.61^{\mathrm{d}} \pm 0.01$ \\
\hline
\end{tabular}

Values are means \pm standard deviation of duplicate determination

Means with the same superscript within the column are not significantly different ( $>0.05$ ) while different superscript within the column are significantly different $(\mathrm{p}<0.05)$.

KEY:

Sample A= White boiled cassava

Sample B $=$ White stirred cassava

Sample $\mathrm{C}=$ Yellow boiled cassava

Sample $\mathrm{D}=$ Yellow stirred cassava

TABLE 2: The microbial load of fufu

\begin{tabular}{llll}
\hline Sample & Day 1 $(c f u / g)$ & Day 3 $(c f u / g)$ & Day $7(c f u / g)$ \\
\hline A & $2.06 \times 10^{3 \mathrm{~d}} \pm 0.01$ & $4.13 \times 10^{3 \mathrm{c}} \pm 0.12$ & $9.67 \times 10^{5 \mathrm{a}} \pm 0.02$ \\
B & $9.38 \times 10^{3 \mathrm{a}} \pm 0.02$ & $9.48 \times 10^{3 \mathrm{a}} \pm 0.06$ & $1.12 \times 10^{5 \mathrm{~d}} \pm 0.02$ \\
C & $3.86 \times 10^{3 \mathrm{~b}} \pm 0.06$ & $4.17 \times 10^{3 \mathrm{~b}} \pm 0.06$ & $1.32 \times 10^{5 \mathrm{c}} \pm 0.02$ \\
D & $2.64 \times 10^{3 \mathrm{c}} \pm 0.05$ & $4.17 \times 10^{3 \mathrm{~b}} \pm 1.20$ & $1.74 \times 10^{5 \mathrm{~b}} \pm 0.05$ \\
\hline
\end{tabular}

Values are means \pm standard deviation of duplicate determination

Means with the same superscript within the column are not significantly different $(p>0.05)$ while different superscript within the column are significantly different $(\mathrm{p}<0.05)$.

KEY:

Sample A= White boiled cassava

Sample B= White stirred cassava

Journal of the Faculty of Agriculture and Veterinary Medicine, Imo State University Owerri website: $w w w$ ajol.info 
Journal of Agriculture and Food Sciences

Volume 17 Number 1, April 2019 pp 18-3̧7

Amadi, Joy A.C. and Njoku, Sylvarlene M. 34

Sample $\mathrm{C}=$ Yellow boiled cassava

Sample D= Yellow stirred cassava

$\mathrm{CFU}=$ Colony Forming Unit

Table 3a: Changes in the physical appearance of the white boiled cassava fufu stored for 7 days.

\begin{tabular}{llll}
\hline Days & Colour observation & Odour & Overall \\
\hline 1 & No visible colour & No odour & No visible change \\
2 & No visible colour & No odour & No visible change \\
3 & No visible colour & No odour & No visible change \\
4 & White spots & Mouldy smell & Partial spoilage \\
5 & Deep yellow & Mouldy smell & Spoilage \\
6 & Green spots & Mouldy smell & Profuse spoilage \\
7 & Dirty brown & Mouldy smell & Profuse spoilage \\
\hline
\end{tabular}

Table 3b: Changes in the physical appearance of the white stirred cassava fufu stored for 7 days.

\begin{tabular}{llll}
\hline Days & Colour observation & Odour & Overall \\
\hline 1 & No visible colour & No odour & No visible change \\
2 & No visible colour & No odour & No visible change \\
3 & No visible colour & No odour & No visible change \\
4 & White spots & Mouldy smell & Partial spoilage \\
5 & Yellow spot & Mouldy smell & Spoilage \\
6 & Greenish spots & Mouldy smell & Profuse spoilage \\
7 & Brown & Mouldy smell & Profuse spoilage \\
\hline
\end{tabular}

Journal of the Faculty of Agriculture and Veterinary Medicine, Imo State University Owerri website: www ajol.info 
Table 3c: Changes in the physical appearance of the yellow stirred cassava fufu stored for 7 days.

\begin{tabular}{llll}
\hline Days & Colour observation & Odour & Overall \\
\hline 1 & No visible colour & No odour & No visible change \\
2 & No visible colour & No odour & No visible change \\
3 & No visible colour & No odour & No visible change \\
4 & No visible colour & No odour & No visible change \\
5 & White spot & No odour & Spoilage \\
6 & White colour & Mouldy smell & Spoilage \\
7 & Whitish yellow & Mouldy smell & Profuse spoilage
\end{tabular}

Table 3d: Changes in the physical appearance of the yellow boiled cassava fufu stored for 7 days.

\begin{tabular}{llll}
\hline Days & Colour observation & Odour & Overall \\
\hline 1 & No visible colour & No odour & No visible change \\
2 & No visible colour & No odour & No visible change \\
3 & No visible colour & No odour & No visible change \\
4 & No visible colour & No odour & No visible change \\
5 & No visible colour & No odour & No visible change \\
6 & Whitish yellow & Mouldy smell & Spoilage \\
7 & Whitish yellow & Mouldy smell & Profuse spoilage \\
\hline
\end{tabular}


Table 4: Socioeconomics characteristics of the respondents

\begin{tabular}{|c|c|c|}
\hline Variables & Frequencies & Percentages \\
\hline \multicolumn{3}{|l|}{ Sex } \\
\hline Male & 101 & 33.7 \\
\hline Female & 199 & 66.3 \\
\hline \multicolumn{3}{|l|}{ Age } \\
\hline $20-30$ & 44 & 14.7 \\
\hline $31-40$ & 99 & 33.0 \\
\hline $41-50$ & 105 & 35.0 \\
\hline $51-60$ & 52 & 17.3 \\
\hline \multicolumn{3}{|l|}{ Marital status } \\
\hline Single & 60 & 20.0 \\
\hline Married & 148 & 49.3 \\
\hline Divorced & 12 & 4.0 \\
\hline Widowed & 79 & 26.3 \\
\hline \multicolumn{3}{|l|}{ Education } \\
\hline No formal education & 37 & 12.3 \\
\hline FSLC & 78 & 26.0 \\
\hline WASC & 104 & 34.7 \\
\hline Degree & 72 & 24.0 \\
\hline Masters degree & 8 & 2.7 \\
\hline Ph.D & 1 & 0.3 \\
\hline \multicolumn{3}{|l|}{ Occupation } \\
\hline Public servant & 49 & 16.3 \\
\hline Trader & 131 & 43.7 \\
\hline Civil servant & 120 & 40.0 \\
\hline \multicolumn{3}{|l|}{ Income（華) } \\
\hline$<10,000$ & 101 & 33.7 \\
\hline$<50,000$ & 124 & 41.3 \\
\hline$<100,000$ & 58 & 19.3 \\
\hline$>100,000$ & 17 & 5.7 \\
\hline
\end{tabular}

Table 5: Consumers' preference

Journal of the Faculty of Agriculture and Veterinary Medicine, Imo State University Owerri website: www ajol.info 
Journal of Agriculture and Food Sciences

Amadi, Joy A.C. and Njoku, Sylvarlene M. 37 Volume 17 Number 1, April 2019 pp 18- 37

\begin{tabular}{|c|c|c|}
\hline Variables & $\begin{array}{l}\text { Frequencies } \\
\mathbf{n}=\mathbf{3 0 0}\end{array}$ & $\begin{array}{l}\text { Percentages } \\
(\%)\end{array}$ \\
\hline \multicolumn{3}{|l|}{ Preferred method of preparation } \\
\hline Boiling & 228 & 76.0 \\
\hline Stirring & 72 & 24.0 \\
\hline \multicolumn{3}{|l|}{ Method used } \\
\hline Boiling & 227 & 75.7 \\
\hline Stirring & 73 & 24.3 \\
\hline \multicolumn{3}{|l|}{ Reason for preference } \\
\hline Colour & 20 & 6.7 \\
\hline Texture & 68 & 22.7 \\
\hline Odour & 81 & 27.0 \\
\hline Taste & 57 & 19.0 \\
\hline Longer shelf life & 38 & 12.7 \\
\hline All of the above & 36 & 12.0 \\
\hline \multicolumn{3}{|l|}{ Easy to prepare } \\
\hline Boiled fufu & 134 & 44.7 \\
\hline Stirred fufu & 166 & 55.3 \\
\hline \multicolumn{3}{|l|}{ Preparation procedure with high quality } \\
\hline Boiled fufu & 147 & 49.0 \\
\hline Stirred fufu & 153 & 51.0 \\
\hline \multicolumn{3}{|l|}{ Major problem during preparation } \\
\hline Much energy is required during pounding & 134 & 44.7 \\
\hline Much water is not needed during stirring & 96 & 32.2 \\
\hline Cassava peeling is time consuming & 54 & 18.0 \\
\hline No response & 16 & 5.3 \\
\hline \multicolumn{3}{|l|}{ improvement in cassava preparation } \\
\hline Use of automated machine & 172 & 57.3 \\
\hline $\begin{array}{l}\text { Fairly prepared fufu should be made } \\
\text { available }\end{array}$ & 54 & 18.0 \\
\hline No response & 74 & 24.7 \\
\hline
\end{tabular}

Journal of the Faculty of Agriculture and Veterinary Medicine, Imo State University Owerri website: www ajol.info 